\title{
EXPORTING SPANISH FIRMS. STYLIZED FACTS AND TRENDS
}

Eduardo Gutierrez chacon

and Cesar Martín Machuca

Documentos ocasionales

N. 1903

BANCO ESPANA

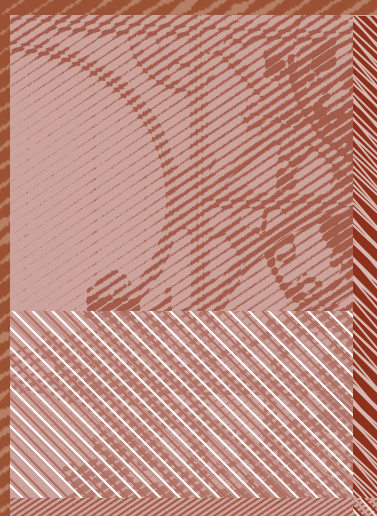

Eurosistema 
EXPORTING SPANISH FIRMS. STYLIZED FACTS AND TRENDS 
EXPORTING SPANISH FIRMS. STYLIZED FACTS AND TRENDS ${ }^{*}$

Eduardo Gutiérrez Chacón and César Martín Machuca

BANCO DE ESPAÑA

${ }^{(*)}$ The views expressed in this paper are the authors' and do not necessarily reflect those of the Banco de España

or the Eurosystem. Correspondence to: César Martín Machuca (cmartin@bde.es), Directorate General Economics, Statistics and Research, Banco de España, C/ Alcalá, 48, 28014 Madrid, Spain.

Documentos Ocasionales. N. ${ }^{\circ} 1903$

2019 
The Occasional Paper Series seeks to disseminate work conducted at the Banco de España, in the performance of its functions, that may be of general interest.

The opinions and analyses in the Occasional Paper Series are the responsibility of the authors and, therefore, do not necessarily coincide with those of the Banco de España or the Eurosystem.

The Banco de España disseminates its main reports and most of its publications via the Internet on its website at: http://www.bde.es.

Reproduction for educational and non-commercial purposes is permitted provided that the source is acknowledged.

C BANCO DE ESPAÑA, Madrid, 2019

ISSN: 1696-2230 (on-line edition) 


\section{Abstract}

During the last years, Spanish goods exports have increased significantly against a background of widening of the Spanish firms exporting base. This change has been led by SMEs, although there is still a high concentration of international sales in a small fraction of large and stable exporters. In any case, potential export growth has improved thanks to the widening of stable exporters base and to their geographical diversification towards emerging markets. Exporting firms are greater and have higher labour productivity than those focused only in domestic markets. Also within exporting firms, those with stable and diversified external flows are positively selected in terms of productivity and size. The potential widening of the stable exporting base would require an improvement of the efficiency of the segment of SMEs. Removing potential regulatory barriers that might restrict their growth and innovation ability is key to consolidate their presence in international markets in the long run.

Keywords: international trade, exports, firms, geographical diversification.

JEL classification: F1, F14, F19, F23. 


\section{Resumen}

En los últimos años, las exportaciones españolas han aumentado significativamente, en un contexto de ampliación de la base de empresas exportadoras españolas, liderada por las PYMes, aunque las ventas al exterior están concentradas en una pequeña fracción de exportadores grandes y estables. En cualquier caso, el crecimiento potencial de las exportaciones ha mejorado gracias a la ampliación de la base estable de exportadores y a la diversificación geográfica hacia mercados emergentes. Las empresas exportadoras son más grandes y productivas que aquellas que solo operan en el mercado nacional. A su vez, dentro de los exportadores, las empresas estables y más diversificadas geográficamente son más eficientes y de mayor tamaño que el resto de las compañías presentes en los mercados internacionales. Ampliaciones adicionales de la base exportadora estable requieren mejoras de la eficiencia del segmento de las PYMes. La eliminación de los obstáculos que restringen el crecimiento y la capacidad de innovación de estas empresas es un factor clave para consolidar su presencia en los mercados internacionales a largo plazo.

Palabras clave: comercio internacional, exportaciones, empresas, diversificación geográfica.

Códigos JEL: F1, F14, F19, F23. 
INDEX

Abstract 5

Resumen 6

1 Introduction 8

2 Data 9

3 Main trends in the base of Spanish exporters 10

3.1 Spanish exporting base: increasing SMEs participation 10

3.2 Regular exporting firms continued expansion even in the expansionary phase 11

3.3 Exporting firms geographical diversification: increasing role of non-EU markets 12

3.4 Exporting firms by technological content: specialization on low and medium-low products 16

3.5 Exporting firms base developments during $2018 \quad 17$

4 Main characteristics of the base of Spanish exporting firms 18

5 Concluding remarks 19

References 21 


\section{Introduction}

The increase in the number of Spanish firms that engage in foreign trade investment is a good indicator of the renewed process of internationalization that Spain has experienced since the last crisis. The adjustment of domestic demand during the crisis encouraged Spanish firms to seek new foreign markets, which in turn contributed to reduce structural current account deficit. The subsequent recovery did not imply a reversal of this trend although it resulted in a certain slowdown in the regular exporting base, whose behavior is determinant to assess the expectations about export potential growth since foreign sales intensive margin is determined in a large extent by regular exporters. As a result, analysis of an economy's competitiveness is increasingly focused not only on the traditional aggregate indicators, based on relative prices and costs, but also on the evolution of exporting firms' base and their characteristics.

The aim of this article is to analyze the main stylized facts and characteristics of Spanish firms that export goods. For this purpose, we employ two main databases: in order to capture the main characteristics of exporters' base recent developments we use ICEX from Customs Data. Second, exporting firms characteristics are analyzed thanks to a specific database which has been built using three different statistical sources: the Balance of Payments, the Central Balance Sheet Data Office and the annual accounts that companies file with the Mercantile Registries.

According to the research undertaken, the number of Spanish firms engaging in crossborder trade expanded 30\% over the period 2011-17. During that period regular export base also widened, including the most recent period of economic recovery. SMEs led the widening of exporting firms base, although their low rates of survival in export activity contribute to maintain the high concentration of sales abroad in a small fraction of large and stable exporters. Potential exports growth has improved thanks to the widening of stable exporters base and to the geographical diversification towards emerging markets, although EU still accounts for the bulk of exports (around 2/3).

Concerning exporting firms' characteristics, exporters are bigger and have higher labor productivity than those firms focused on the domestic market, since they are better placed to face the higher degree of competition existing in world markets. There is also a positive gap among exporting firms when we split between regular and non-regular exporters and when we consider the geographical diversification degree. So in an environment surrounded by risks related to protectionist revival and the outcome of Brexit negotiations between EU and UK concerning international trade, the vulnerability of Spanish exporting firms may be reduced by their idiosyncratic characteristics.

The rest of the article is organized as follows. The second section describes briefly the data used. The next section focuses on the changes in recent years in the base of Spanish exporters using data compiled by the ICEX. The fourth section analyses the characteristics of the firms behind these developments using micro data on cross-border transactions. Finally, the main conclusions are set out in the last section. 


\section{Data}

In this paper, we use two main databases in order to analyze the main trends and stylized facts of Spanish exporting firms. The dynamics of exporters' base and sales abroad are described using ICEX data on exporting firms. ICEX employs Customs data, whereby their Spanish external trade coverage is total. Data frequency is monthly, although yearly and accumulated within one year figures are requested from ICEX web. ${ }^{1}$

ICEX provides information about the number of exporters, split between regular and nonregular (the former are firms that export at least four years on a row). Information about exporters also considers the geographical and product dimensions. The degree of product disaggregation reaches 5 digits. All this information can be retrieved from ICEX web also for exported values per firm. Unfortunately, ICEX does not provide information about firms' characteristics, such as size, hence firms' size may be proxied by exported value by year. In this paper, exporter SMEs (until 249 employees) includes businesses that sell abroad less than 1 million Euros. The percentage of SME exporting firms that results from applying this threshold is similar to the one provided by the AET in the yearly report External Trade Data by Firms Characteristics.

Additionally, ICEX classifies trade in four categories by technological intensity: high, medium-high, medium-low and low. The classification is done by determining the technological adoption of industries in which products are included. Technological adoption is defined in terms of the share of R\&D expenditures. Exporting firms' characteristics (such as number employees, debt ratio or labour productivity) can be analyzed through a specific database for 2001-2013 period that incorporates information from three different statistical sources. First, the firms that conduct cross-border goods transactions and the value of such transactions are identified through the Balance of Payments statistics. ${ }^{2}$ Second, in order to approximate the main distinguishing characteristics of this group of firms, this information is cross-checked with that of the Central Balance Sheet Data Office and that of annual accounts filed at the Mercantile Registries. The cross-checking of these databases reduces the number of firms in the sample, since information is not available on all variables for all exporting firms. In addition, it should be noted that the Central Balance Sheet Data Office summarizes the information provided to the Banco de España by firms representing around 30\% of the total value added of the Spanish economy's non-financial corporations. The sample has not been designed using criteria of statistical representativeness, since the collaboration of firms is voluntary. Consequently, the various different economic activities are represented unevenly. In order to mitigate this limitation Mercantile Registry data are also used. In any case, the coverage of the total value of exports is representative, being at least $50 \%$ of the value of exports according to the Balance of Payments statistics.

1 It should be noted that yearly data contain more information that minor periods (specifically concerning exported values bands by firm and their seniority).

2 The information reported by firms on the value of their goods exports and imports for the Balance of Payments differs from that reported to Customs and Excise, which is the official source for this type of transaction. The differences are mainly explained by the existence of a different threshold for simplification of the declaration and by methodological aspects. However, comparison of the information available in these two databases shows that the value of exports declared by firms for the Balance of Payments is on average 95\% of the value according to Customs data. As for exporting firms, the number of firms identified in the Balance of Payments statistics represents around $60 \%$ of those that make up the Customs data, with small firms under-represented in the database constructed. 


\section{Main trends in the base of Spanish exporters}

\subsection{Spanish exporting base: increasing SMEs participation}

Foreign markets significance for Spanish firms has increased in the last years. According to ICEX data, the number of exporters grew around 30\% between 2011 and 2017, to a total of 161,454 . This growth was particularly remarkable during the last recession, specifically in 2012 and 2013, since domestic market was depressed and going abroad was an imperative for Spanish firms, against a background in which the moderation of labour costs, and subsequently of financial costs, strengthened the competitive position of Spanish firms (see Chart 1) (see Banco de España, 2017; Almunia et al., 2018). These developments have implied an increase in the relative share of exporters over the total number of firms, which augmented by more than 1 pp, until near 5\% of the total in 2017.

Specifically, we consider as SMEs those firms whose exports amount to less than one million euros. The widening of exporters base is explained by SMEs (proxied by export value bands, as explained in Section 2), which have accounted for most of the increase in the number of exporting firms since 2011 (near 95\% of the total). Also the exporting SMEs growth rate has been higher (33\% against 16\% in the case of big firms). Thus, in line with international empirical evidence, most of exporters are SMEs (over 90\% of total). Still, the relative weight of exporters in the whole firms population is much higher in the case of big firms than in the case of SMEs (62\% and near 5\%, respectively). So, although technological and logistic advances and the deregulation of trade have reduced export costs also for SMEs, on average, their lower productivity and higher borrowing costs continue to hinder their penetration of and sustained presence in foreign markets (see González and Martín, 2015). On the other hand, it should be kept in mind that exporting SMEs are highly heterogeneous, since they include a range extending from microfirms (maximum of nine employees) to firms of up to 249 employees. $^{3}$

The value of Spanish goods exports grew steadily over 2011-2017 period, with an accumulated rate of growth of $29 \%$ (see Chart 3). Most of the increase was due to major operations (more than 250 million euros). So, in contrast with exporting base evolution, exported values are led by big firms, which account for almost the whole of this increase. In fact, the concentration of exported value has increased over the analyzed period: 10\% top exporters represented 97.5\% of sales abroad in 2017 (1.5 pp more than in 2011). In the 2011-2017, there was no a clear path for average exported value per firm, which remained relatively stable in general terms. ${ }^{4}$

3 This heterogeneity is reflected, according to AET data, in the high dispersion of the proportion of SMEs which export in each size tranche, since it is only around 2\% in micro firms and over 40\% in firms with 200 to 249 employees, in line with international evidence (see European Commission, 2014).

4 This degree of concentration is similar to that estimated in Mayer and Ottaviano (2007) for other European economies (specifically, Germany, France, the United Kingdom, Italy, Hungary, Belgium and Norway), although the relative weight of the largest $1 \%$ of exporting firms tends to be higher in Spain than in these economies. 
1 EXPORTERS BY SIZE

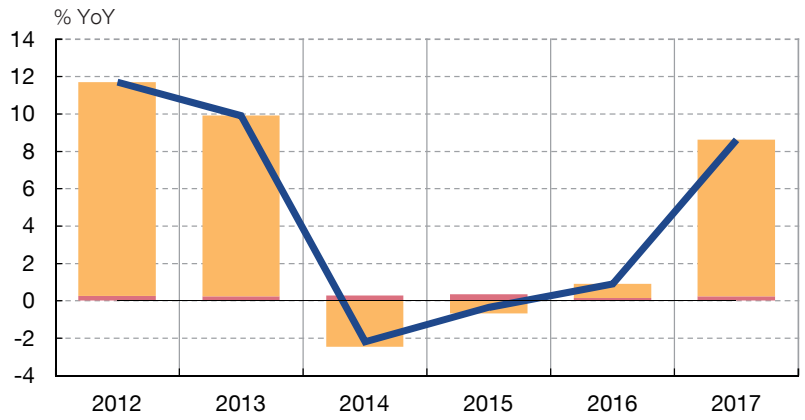

BIG FIRMS SME (a) TOTAL

3 SHARE OF EXPORTERS BY SIZE

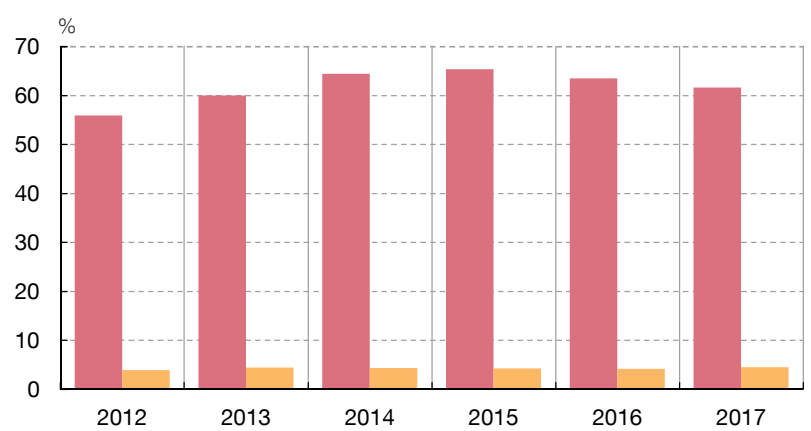

BIG FIRMS

5 SHARE OF REGULAR OVER TOTAL EXPORTERS

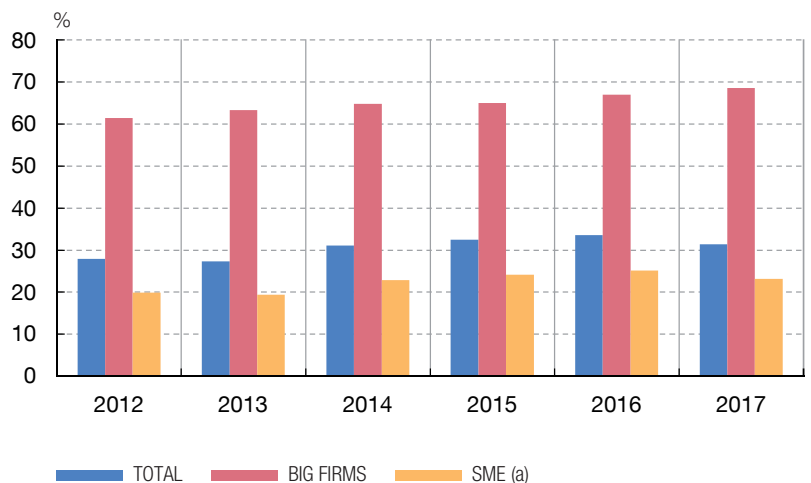

2 EXPORTERS SHARE

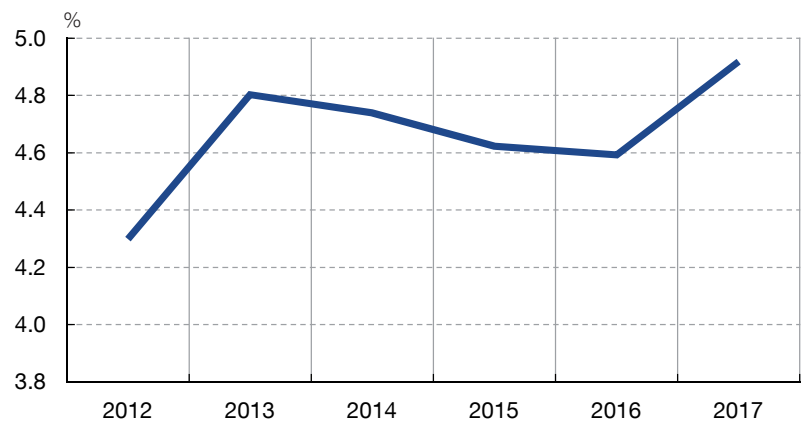

4 REGULAR EXPORTERS

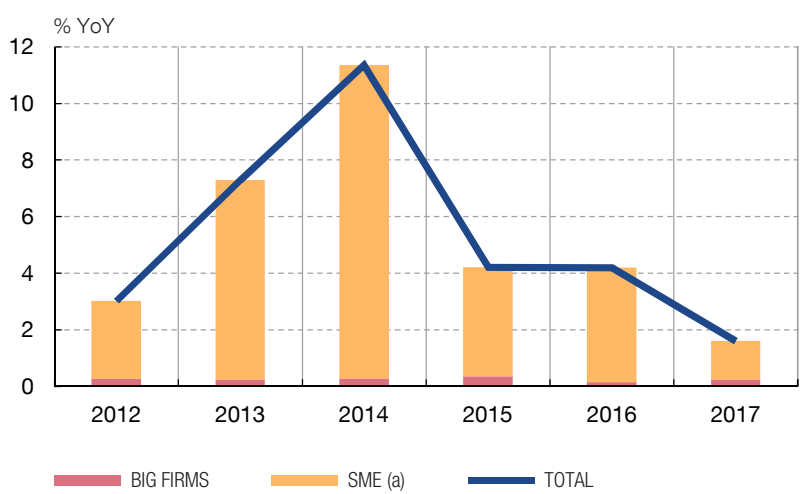

6 SHARE OF REGULAR EXPORTERS OVER TOTAL NUMBER OF FIRMS

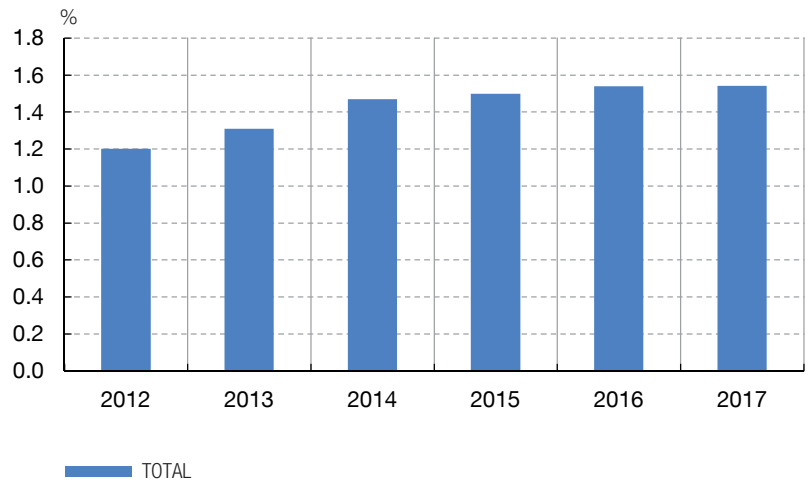

SOURCES: Banco de España and ICEX.

a SME includes those that report transactions below 1 million euros.

\subsection{Regular exporting firms: continued expansion even in the expansionary phase}

The expansion over the period 2011-2017 in the base of Spanish exporters was accompanied by a constant increase in the number of regular exporters (36\% over the same period, up to 50,562), defined as those firms that export at least four consecutive years. As a result of this expansion, the relative share of regular exporters in the total firms' population augmented by 0.4 pp between 2011 and 2017, although the share has remained relatively stable around 30\% 
$\%$ of those beginning in 2010

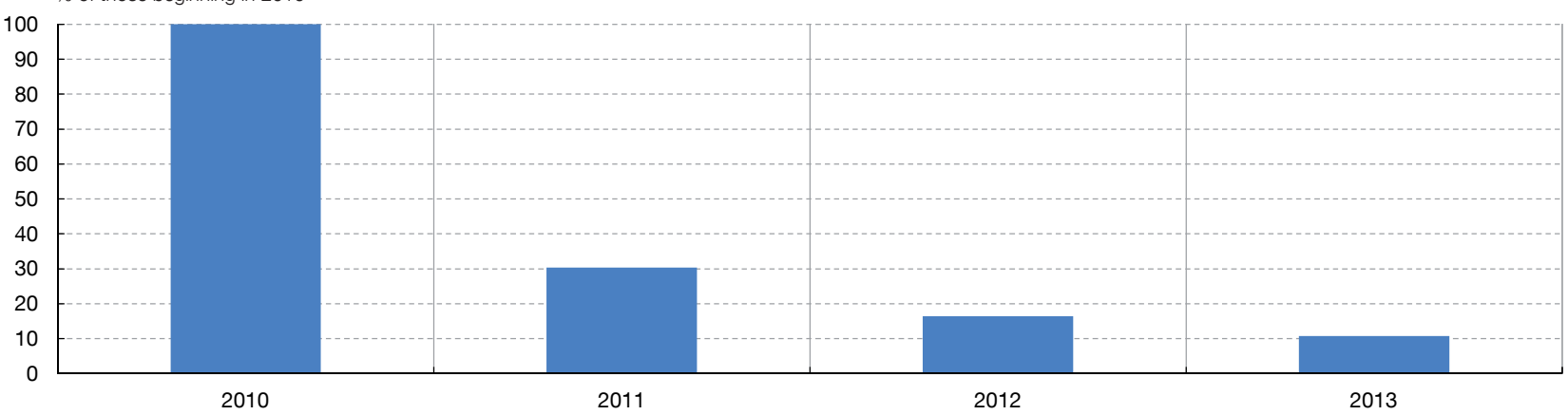

SOURCE: Banco de España.

when only exporting firms are considered. Accumulated growth of regularly exporting SMEs has been more acute than that shown by big firms (44\% against 27\%). Again, although SMEs account for most of stable exporters (approximately 2/3) and of their accumulated increase in 2011-2017 period (77\%), the percentage of stable exporters within big firms is much higher than in the case of SMEs (near $70 \%$ and $25 \%$, respectively).

The instability of new trade relationships hinders exporters from becoming stable (see Chart 2). When we consider the trade relationships generated in 2010 , only around $10 \%$ turned stable. Empirical evidence shows that the survival of SMEs in export activity is appreciably lower than that of large firms and is positively correlated with firm size (see González and Martín, 2015). SMEs have certain difficulty in sustaining themselves in the international environment (see De Lucio and Fuentes, 2006). The empirical evidence is that stable exporters tend to be larger and more efficient (efficiency being proxied by apparent labour productivity and the performance of R\&D activities) than non-stable exporters (see Galán and Martín, 2012).

Concerning exported values, the evolution of regular exporters' sales abroad is very similar to total exports, since the bulk of big firms, which accounts for most of exports, are stable exporters, as explained previously. Thus, the widening of regular exporters base may explain, at least partially, the positive residuals found in the exports equation (see García and Prades, 2015), since life-cycle dynamics of exporters tends to increase sales abroad in line with experience accumulated in international markets (Gumpert et al., 2017). In fact, since 2011 the share of sales abroad by regular exporters has increased 4 pp, until 95\% of total exports.

\subsection{Exporting firms geographical diversification: increasing role of non-EU markets}

In recent decades, the internationalization of the Spanish economy has been accompanied by a geographical diversification towards non-EU markets, and, especially, emerging markets, whose potential growth is higher than that corresponding to advanced European economies. The progressive entry of new countries onto the international market has not only raised the competitive bar for Spanish firms, but has also provided them with an opportunity, by considerably increasing the potential number of consumers. Thus, the number of exporting 
1 VALUE EXPORTED BY SIZE

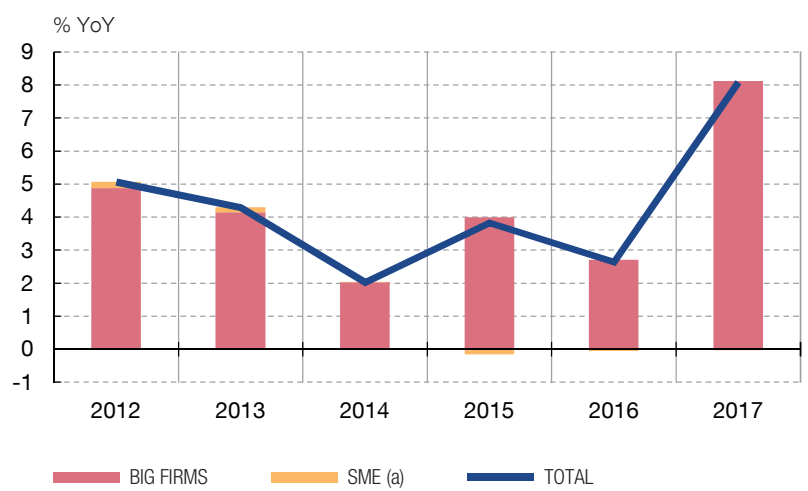

3 VALUE EXPORTED BY SENIORITY

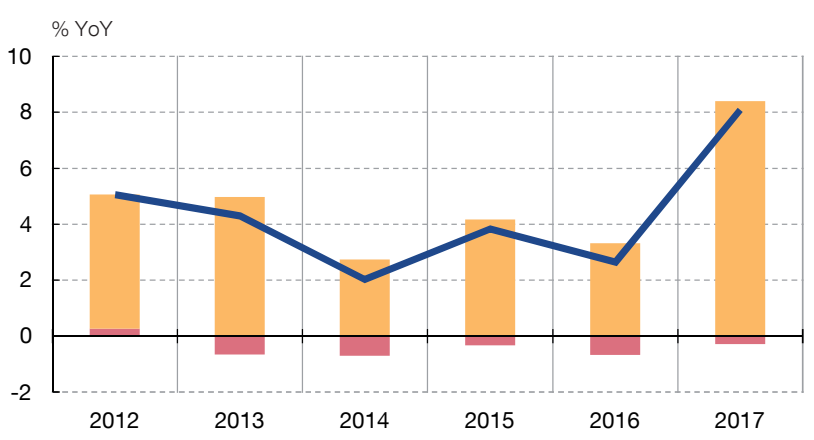

NOT REGULAR REGULAR TOTAL

5 EXPORTERS CONCENTRATION

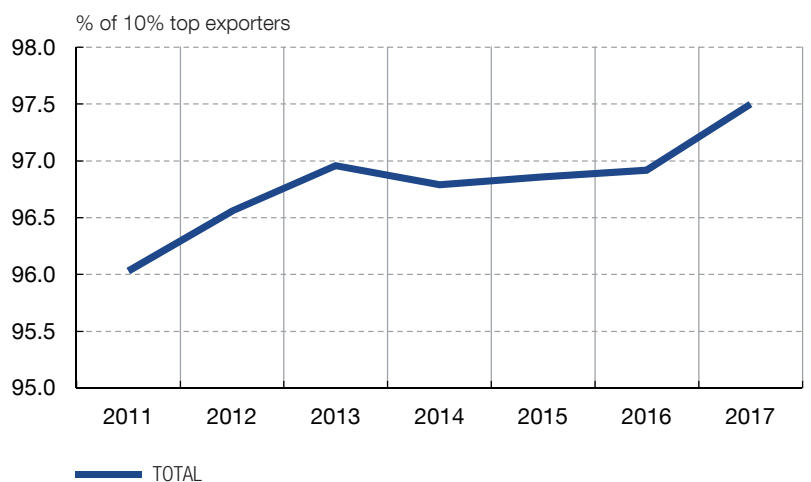

2 VALUE EXPORTED BY AMOUNT

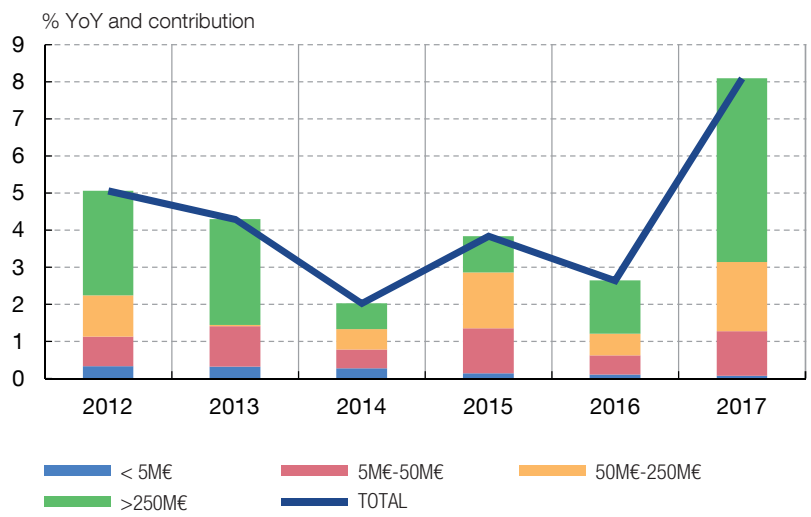

4 VALUE EXPORTED BY REGULAR EXPORTERS

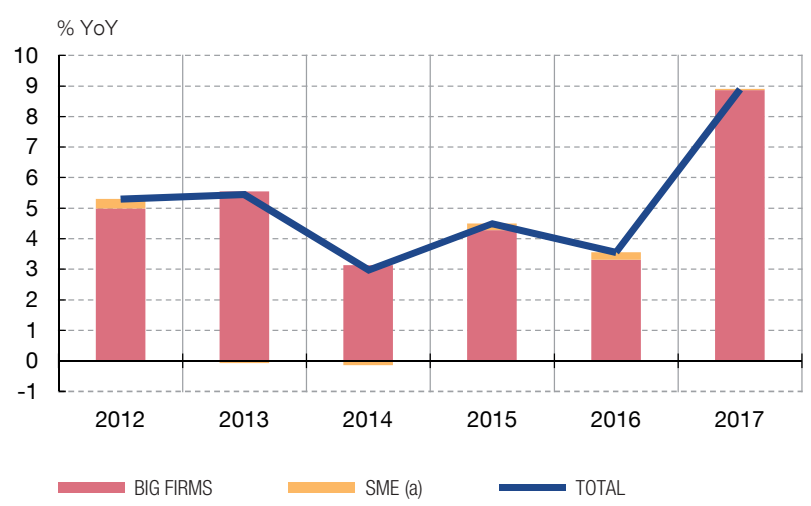

6 AVERAGE EXPORTS BY FIRM

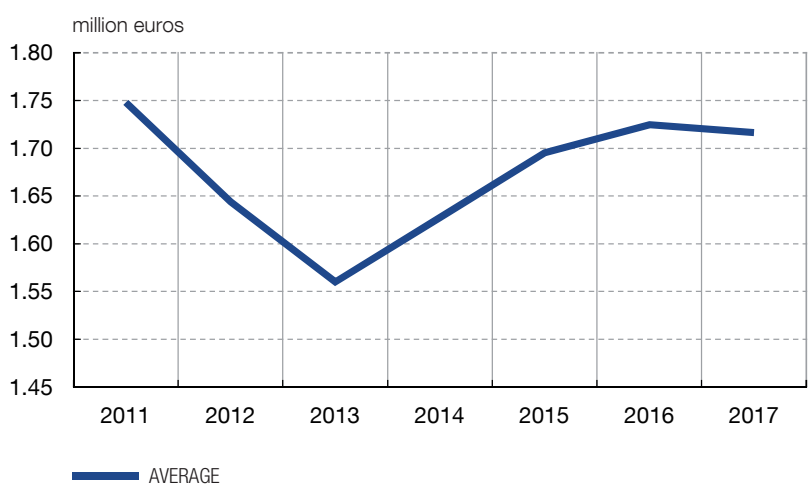

SOURCES: Banco de España and ICEX.

a SME includes those that report transactions below 1 million euros.

firms towards EU only increased less than 3\% between 2011 and 2017, while the widening of exporters base to non EU markets was much more acute (see Chart 4). In particular, it stood out the exporters' base growth to USA and Latin America, with an accumulated rise of approximately 50\%, followed by firms that sell to Asia and Africa ( $27 \%$ and $18 \%$, respectively). These developments have implied a fall in the relative share of EU in the exporting base of around 5 pp, until near 20\% of total. On the contrary, relative weights of Latin America and USA rose by 5 pp and 2 pp. Asian markets share remained relatively stable. 
1 EXPORTERS BY REGION

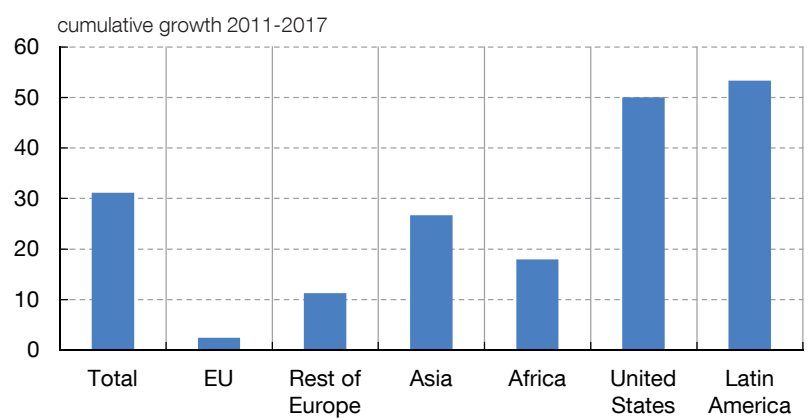

3 REGULAR EXPORTERS BY REGION

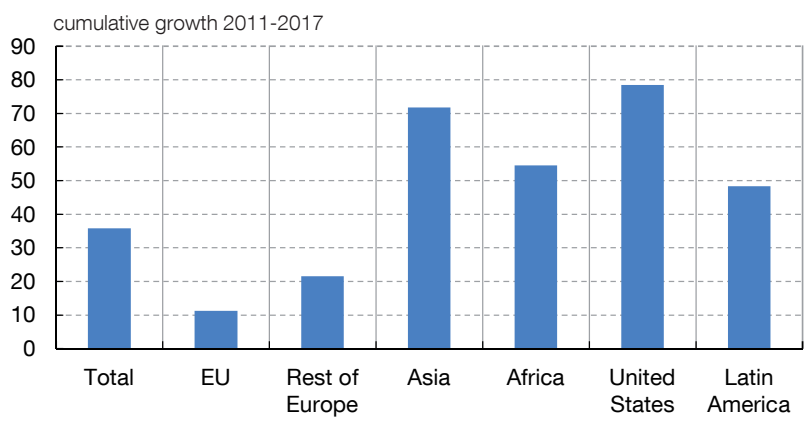

5 EXPORTERS BY REGION AND TECHNOLOGICAL INTENSITY

cumulative growth 2011-2017

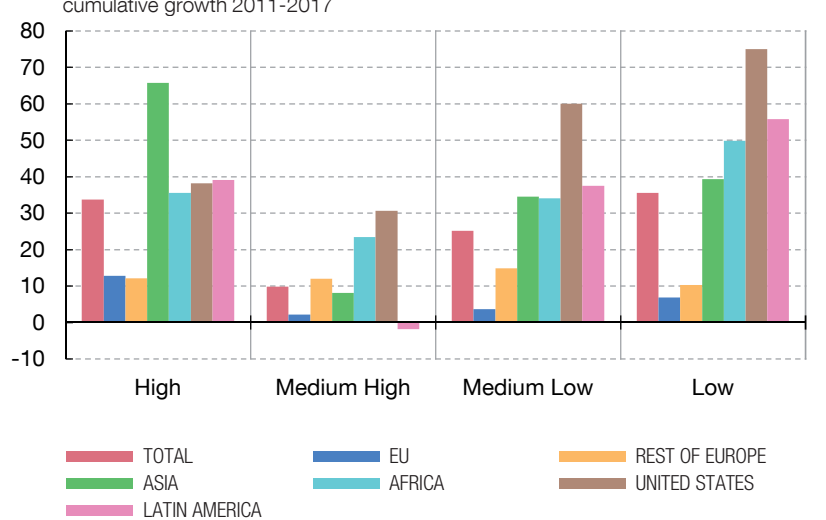

2 SHARE OF EXPORTERS BY REGION

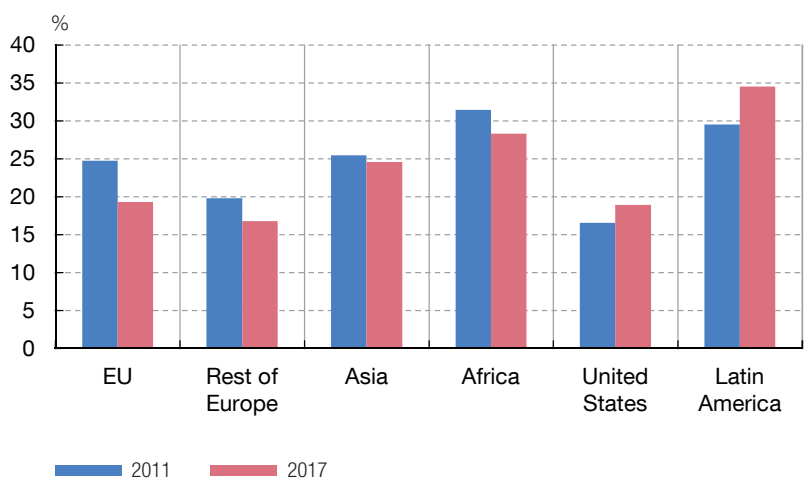

4 REGULAR EXPORTERS SHARE BY REGION

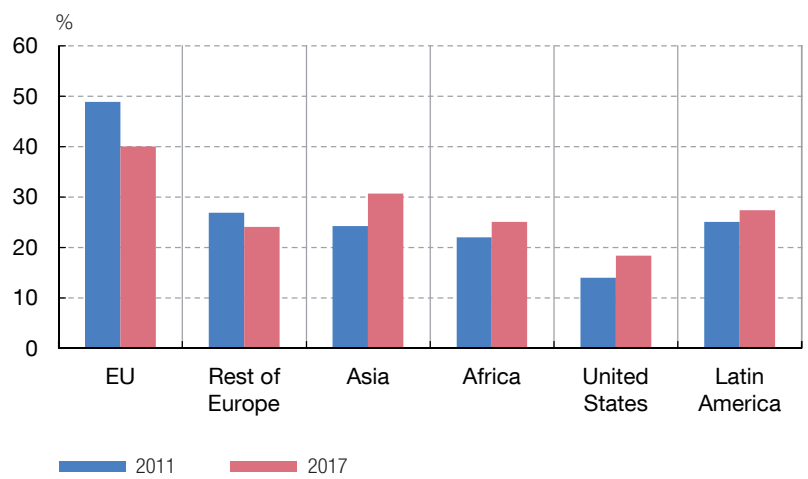

6 EXPORTERS SHARE BY REGION AND TECHNOLOGICAL INTENSITY $\% 2017$

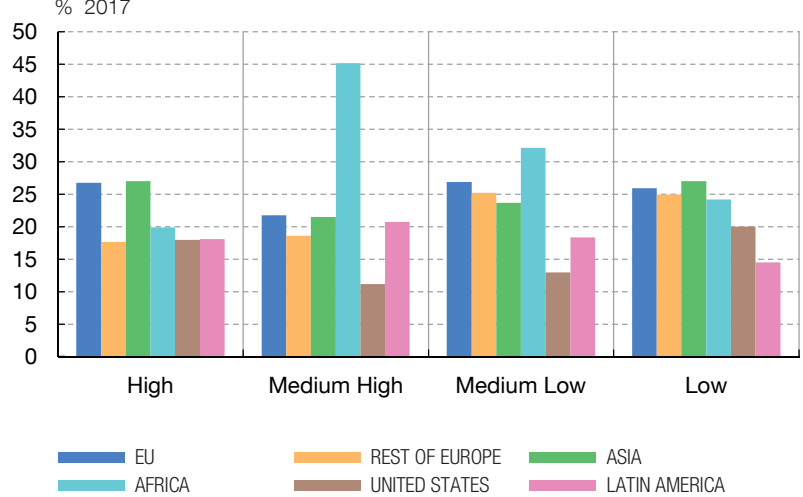

SOURCES: Banco de España and ICEX.

The process of geographical diversification has also been very remarkable in terms of regular exporters. The number of this kind of exporters towards EU accumulated an increase of $11 \%$ in 2011-2017 period, while the range of growth experienced by those firms that sell to US, Asia, Africa and Latin America stood between 50\% and 80\%. It should be noticed that EU markets accumulated the bulk of firms that export above 1 million euros (around 75\%), which explains that the EU still accounts for most of Spanish goods exports (66\% in 2017, according to Customs Data). Spanish penetration in non EU markets is lower due to higher transaction 

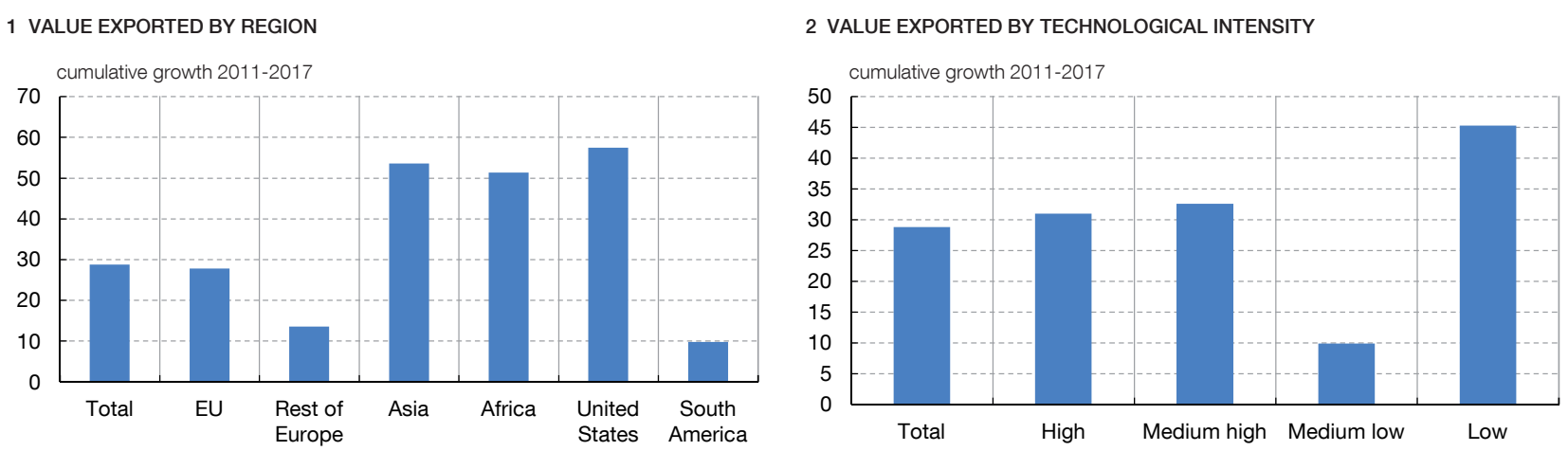

3 VALUE EXPORTED BY REGION

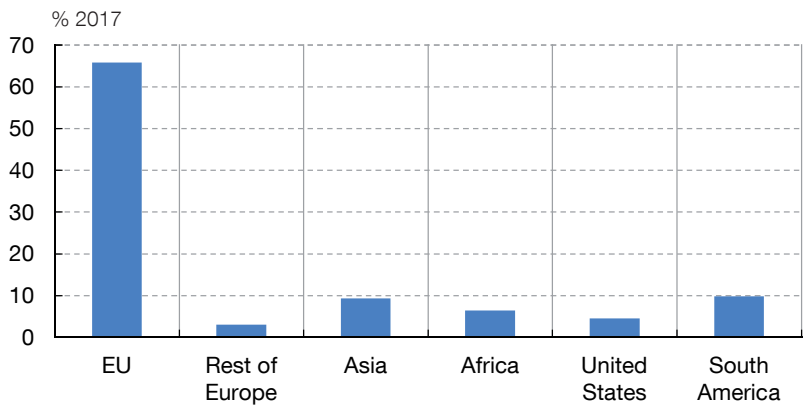

5 VALUE EXPORTED BY REGION AND TECHNOLOGICAL INTENSITY

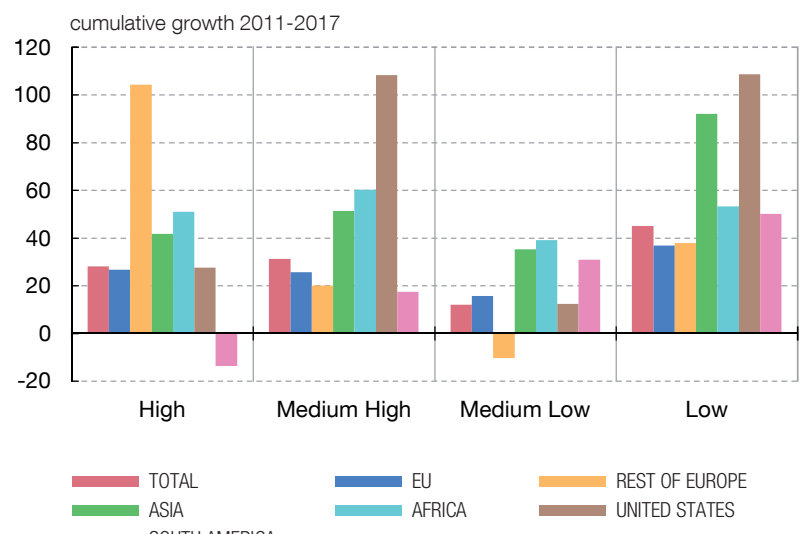

4 VALUE EXPORTED BY TECHNOLOGICAL INTENSITY
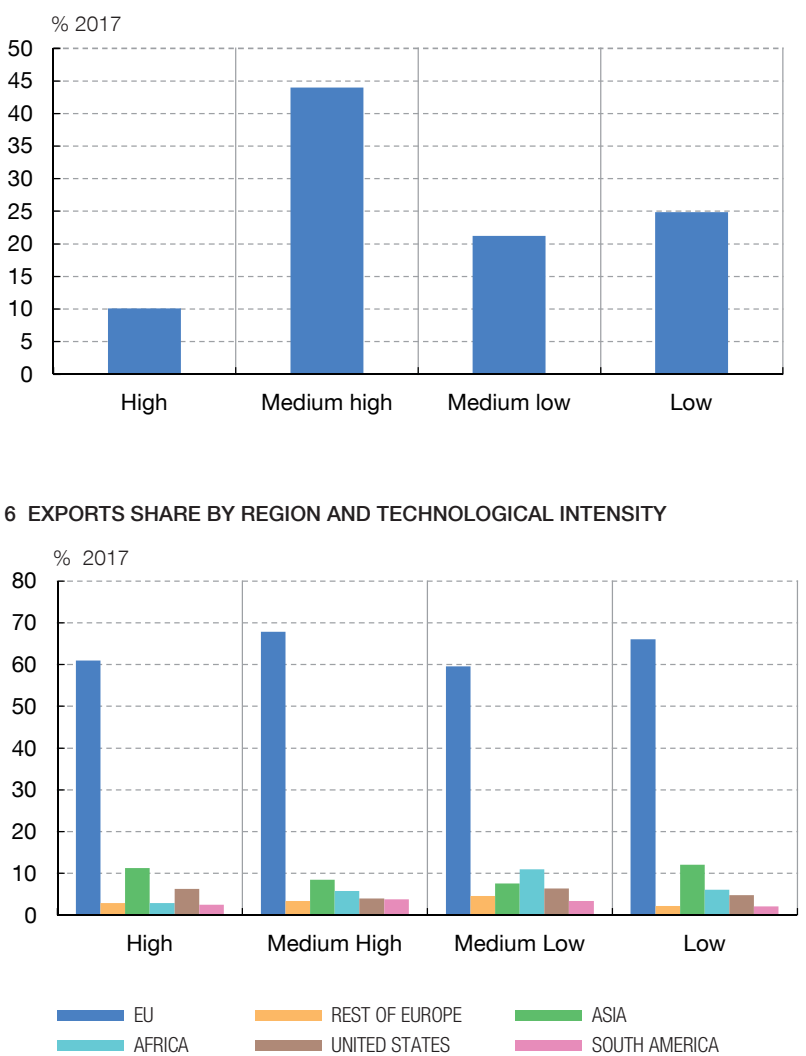

SOURCES: Banco de España and ICEX.

costs and a more mature trade relationship with EU countries. The advances in the consolidation of geographical diversification can be observed through the reduction of the relative weight of EU within stable exporters, which fell by 9 pp until 40\%. On the contrary, Asia and US shares rose (6 pp and 4 pp, up to $31 \%$ and 18\%, respectively). In any case, EU markets yet account for the bulk of big stable firms (75\%), so that the decrease of EU stable share has been focused on firms that exports less than 1 million euros (around 10 pp, down to 25\%).

Exports growth by geographical area was widespread and, in line with exporting firms base behavior, more acute in non-EU markets, especially in USA, Asia and Africa, where growth 


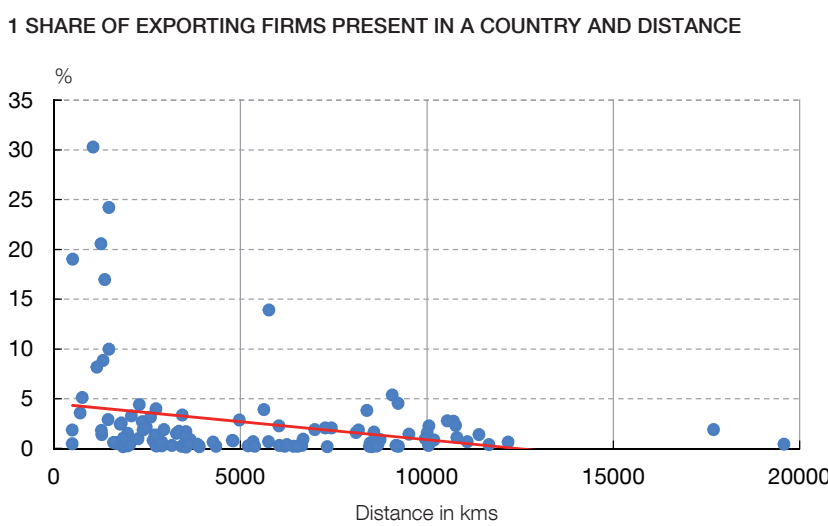

- EXPORTERS
2 VALUE EXPORTED TO A COUNTRY AND DISTANCE

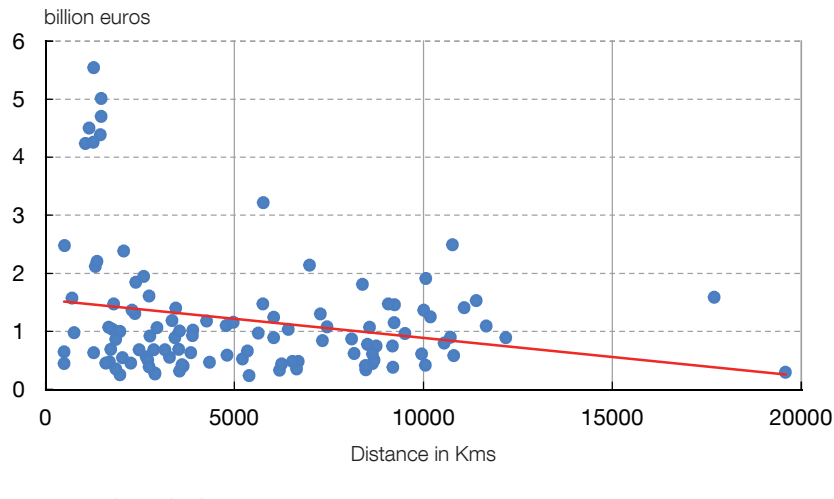

- AVERAGE EXPORTS

SOURCES: Banco de España and CEPII.

rate outpaced overall growth (50\%-60\%), thanks to the entry of new firms. On the other hand, exports to EU grew at a similar rate than total sales abroad (around 30\%), supported by the increase of average exports per firm (see Chart 5). Notwithstanding, EU accumulates a major fraction of total sales abroad (66\%, only 1 pp less than in 2011). So, although Spanish exporting base geographical diversification has advanced in recent years, there still remains a margin of improvement, since the EU represents around two thirds of the total goods exports, and the Spanish products presence in developing markets, with better growth outlook, is more reduced than the one of the countries around us. The number of exporting firms tends to diminish with distance and also the average exported value, due to higher transaction costs (see Chart 6).

The consolidation of regular exports may contribute in the future to further advances in this sense, since, according to empirical evidence, stable exporting firms, sell abroad in a more geographically diversified way than the others, partially due to their international previous experience that lowers the cost of information of entering into new markets (see Galán and Martín, 2012). Besides, a higher diversification reduces the potential vulnerability of the firm to negative shocks from any of its export markets. This increases the probability of maintaining the exporting activity (see De Lucio et al., 2008).

\subsection{Exporting firms by technological content: specialization on low and medium-low products}

In contrast with geographical diversification, by technological content, ${ }^{5}$ there are no clear signs of improvement towards more sophisticated sales abroad, pattern similar to that shown by aggregate Customs data. Spanish exporting firms' base is biased towards medium and low technological content tranches. Exporters' base grew in 2011-2017 period especially in high, medium-low and low tranches (between 25\% and 35\% in accumulated terms), whereas the

5 In ICEX data, very low amount transactions are not classified by branch of activity. As a result, about a third of the companies are not classified, but the accumulated value of non-classified exports is residual, practically negligible. 
advance of medium-high firms was rather lower (10\%). So, the improvement of technological content exporting base was very modest: high tech share only rose 1 pp since 2011 , up to $11 \%$. On the contrary, medium-high tranche relative weight fell by near $5 \mathrm{pp}$, until $36 \%$. The increase in the share of high tech firms was overcome by low tech tranche, whose relative weight rose by $3 \mathrm{pp}$ (up to 32\%), while medium-low firms share was stable. Growth of high content exporting firms was generalized across geographical areas, especially in non-EU markets, with a very high increase in Asia (66\% over 2011-2017 period). In the case of medium-high firms, it stood out the rise of exporters to US and Africa (31\% and 23\%, respectively), while Latin America market fell. US also was the most dynamic area in the case of medium-low and low tech content exporters (60\% and $75 \%$, respectively).

Concerning exported values by technological content, the most dynamic tranche was low tech (45\%), while high and medium-high exports grew in line with total exports. High and low tech exports growth was supported by the widening of the exporting base, while medium-high sales increase was based on rising average exported value by firm. On the contrary, mediumlow tech exports increased at a somewhat lower rate (approximately 10\%). Medium-high tech sales is the tranche with highest relative weight (around 44\%), followed by medium-low and low products, which accumulate approximately $45 \%$ of the total. There were not any significant changes in this pattern along the 2011-2017 period, in line with the evolution of aggregate Customs data and exporting base disaggregation by technological content.

By geographical areas, high tech share exports grew between 2011 and 2017 by around $30 \%$ both in Europe and the rest of the world, while foreign sales of less technologically demanding products increased at a much higher rate in non-European economies. Specifically, European exports increased by 25\%, 15\% and 35\% in the period 2011-2017 for medium-high, medium-low and low tech share tranches; while those destined to further economies increased by $50 \%, 30 \%$ and $80 \%$ respectively.

\subsection{Exporting firms base developments during 2018}

According to latest ICEX data, between January and November of 2018, the number of Spanish exporting companies increased by $33 \%$, largely due to the increase in low-value operations due to the Venezuelan crisis, which biases exporters growth to Latin America upwards. In fact, the rise of stable exporters was substantially less pronounced: $2.4 \%$, reaching 51,362 companies. In the first eleven months of 2018, the geographic diversification of the regular export base continued, with a modest expansion of non-EU markets, while stable exporters to the EU decreased slightly. This evolution has taken place in a context of very moderate growth of Spanish real exports of goods (0.3\%), supported by those destined for the EU, since those directed to the rest of the world fell by $2 \%$, against a background of slowdown of global trade and Euro appreciation which hamper the dynamism of Spanish exports. According to ICEX data, sales to the rest of the world of stable exporters increased by $4 \%$. 


\section{Main characteristics of the base of Spanish exporting firms}

The empirical evidence available, including Spain as analyzed in the previous section, indicates that only a limited proportion of firms export and that these firms are comparatively more efficient and larger than the rest. Specifically, exporting firms are, on average, more capital and technologically intensive, and have a higher level of productivity per employee. These stylized features point to the existence of micro-level determinants of international trade developments. Micro based international trade theories focus on analyzing the characteristics of exporting firms that distinguish them from others, introducing costs of export activity and heterogeneity in firms' productivity levels. So, exporting firms would not be a random sample of the sector of activity to which they belong, but are more efficient than the rest (see Helpman, 2006). In fact, evidence shows that the achievement of this higher productivity precedes the initiation of export activity (see Mauro, Ottaviano and Taglioni, 2007).

The potential vulnerability of firms exporting goods to Brexit and protectionist risks depends on certain intrinsic characteristics of firms themselves. Micro data on cross-border transactions can be used to analyze the differential characteristics of exporting firms. For that purpose, we use 2012 data because is the last year of the database in which the coverage is high and it is not conditioned by the rise of the declaration threshold in 2008.

In line with theoretical predictions and the international and Spanish evidence (see Martín and Rodríguez, 2009), exporting firms are on average larger, have higher levels of productivity, employ fewer temporary workers and are less indebted (see Chart 7). The size gap (measured in terms of employment) between exporting and non- exporting firms is very large (four times). This feature is related with the fact that the proportion of firms that engage in international trade increases with size. At the same time, the temporary employment ratio, which is used to approximate the degree of heterogeneity of the labour factor for a broad sub-set of firms, is around $40 \%$ lower for exporting firms than for those that do not export. The relationship between this variable and the degree of firm efficiency is uncertain: it may affect negatively productivity due to lower levels of experience and training, but may also provide flexibility and facilitate adjustment to shocks. The difference in levels of apparent labour productivity is also notable, this variable being almost $60 \%$ higher in exporting firms than in non-exporting firms.

Having disaggregated geographical information, it is worth analyzing whether differences are discernible among firms that export to different markets. Firms that sell to non-EU markets show higher size and productivity than those that operate in EU, since the former have to face higher transaction costs involved in exporting towards distant (in geographical and/or institutional terms) markets. Microeconomic data used in this article point to some positive relationship between the most productive firms and the degree of geographical diversification. According to previous evidence, firms with steady exports are present in a greater number of countries (see Martín et al., 2009). Therefore, measures aimed at raising Spanish firms' level of productivity and exporting stability might also be conducive to a higher geographical diversification of their 


\section{CHARACTERISTICS OF FIRMS THAT TRADE GOODS}

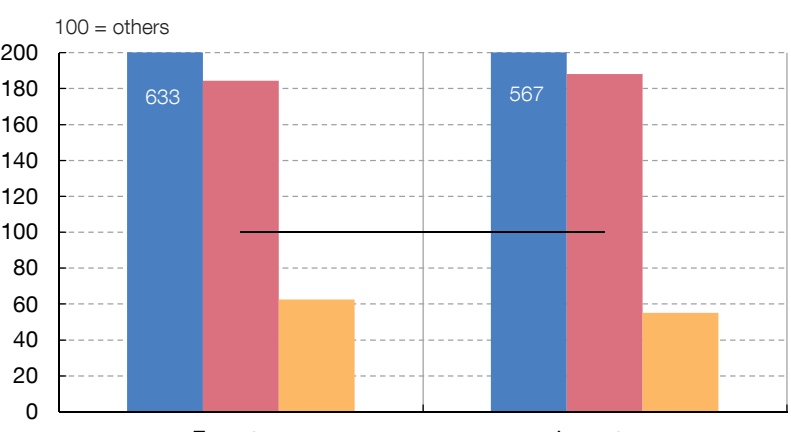

Exporters

Importers
3 EXPORTERS CHARACTERISTICS BY NUMBER OF PARTNERS

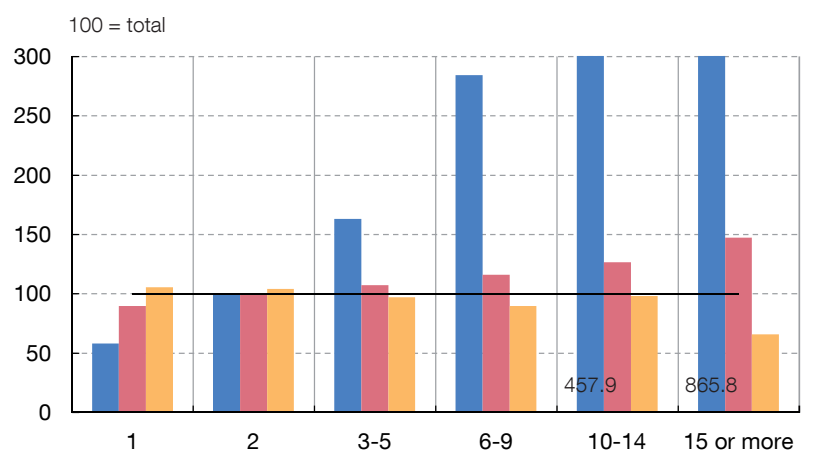

2 EXPORTERS CHARACTERISTICS BY REGION

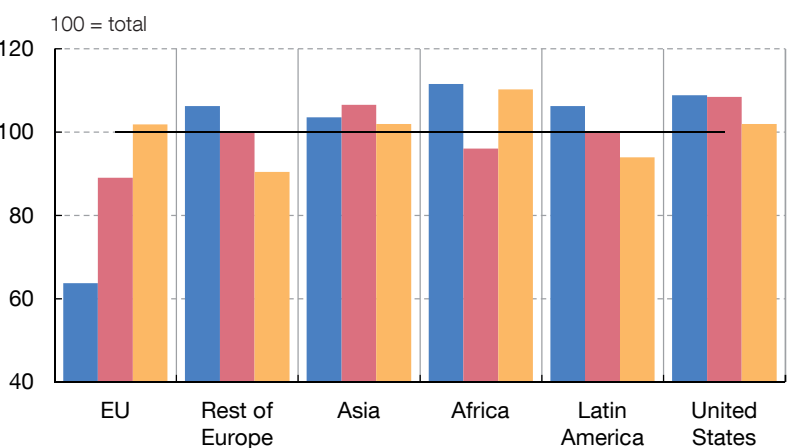

4 EXPORTERS CHARACTERISTICS BY SENIORITY

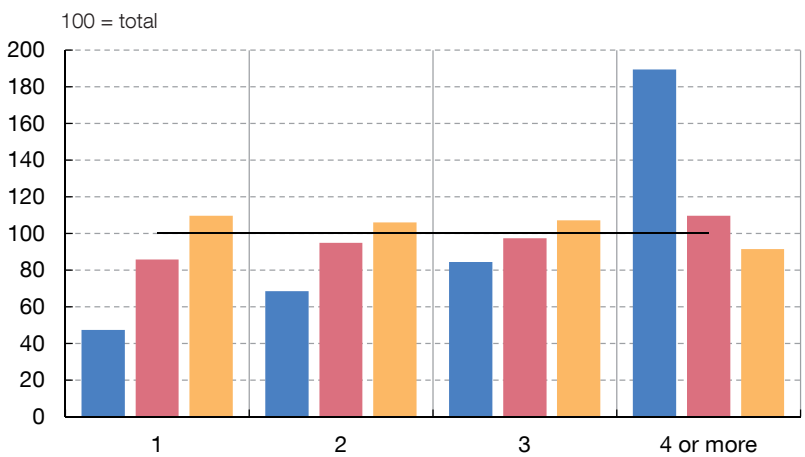

SOURCE: Banco de España.

exports. In addition, a greater geographical diversification also helps to reduce the vulnerability of exporting firms to idiosyncratic shocks in specific markets.

Finally, stable exporters are bigger and have higher labour productivity than those firms that are engaged in exporting activities less than 4 year. Moreover, micro data show that there is a positive relationship between those variables and experience in foreign markets. So, the degree of stability in commercial relations affects positively the growth capacity of exports in the medium term, both due to the gradual increase in the percentage of their sales that stable firms tend to export, as to the influence upon the degree of geographical diversification and the bigger resistance of the export base to cyclical perturbations, as a consequence of the higher efficiency of regular exporters. More productive firms can better face the costs that consolidation in external markets implies and the impact of negative shocks. 


\section{Concluding remarks}

This article describes the main characteristics and recent trends of Spanish goods exporting firms. Over the period 2011-17, the number of Spanish firms engaging in cross-border trade expanded. The widening of Spanish exporting base has not been merely temporary, as a result of a weak domestic demand in the last crisis, since the positive trend of the regular export base is continuing in the most recent period of economic recovery. The concentration of goods exports among firms is very high, in line with the positive association between firm size and the existence of cross-border trade. SMEs led the widening of exporting firms base, although their low rates of survival in export activity show the difficulties such firms have in consolidating their position in the international arena, which contributes to maintain the high concentration of sales abroad in a small fraction of large and stable exporters. In any case, potential exports growth has improved thanks to the widening of stable exporters base and to the geographical diversification towards emerging markets, whose potential growth is higher than that of mature markets such as EU, although the latter still accounts for the bulk of exports (around 2/3).

Spanish exporting firms' characteristics confirm the stylized facts of international evidence: exporters' size is greater than that of firms that only sell to the domestic market and they have higher labour productivity. Also there is a positive gap within exporting firms when we split between stable and non-stable exporters, or in function of the degree of geographical diversification of sales abroad. Thus, exporters to non-EU markets are also bigger and more efficient than those that only compete in EU.

That said, some characteristics of our productive network, such as the predominance of medium or low technological content of exports, the high percentage of SMEs and a lower innovative capacity than in the main developed economies, hinder the expansion and consolidation of Spanish firms abroad, which is a prerequisite to raise average exported value per firm and thus potential export growth in the long run. The potential widening of stable exporting base requires a global improvement of the efficiency of its economy in order to raise the competitiveness and resilience of firms to negative shocks, especially SMEs. Measures aimed at developing more efficient product and factor markets would incentive the reallocation of resources towards the most efficient firms, thereby improving the economy's competitiveness and, thus, its export capacity. Removing the barriers that restrict the growth and innovation capacity of the firms is key to consolidate their presence in the international markets in the long run and to propitiate the firms' penetration in the new emerging markets or with a higher value added. This would reduce the risks involved in the concentration in a low number of markets and it would stimulate the gradual growth of our exports. 


\section{References}

ALMUNIA M., P. ANTRÀS, D. LÓPEZ-RODRÍGUEZ y E. MORALES (2018). "Venting out: exports during a domestic slump», Documento de Trabajo, $n^{\circ} 1844$, Banco de España.

BANCO DE ESPAÑA (2017). "Current Account adjustment», Annual Report 2016, Banco de España.

DE LUCIO, J. J., R. M. FUENTES, M. V. CALERO and G. M. ABEIJÓN (2008). «Permanencia de las empresas en la exportación: una mirada a las características de su actividad exterior», Revista de Economía, n. 840, ICE.

DE LUCIO, F. J. J., and M. R. FUENTES (2006). «Demografía de la empresa española exportadora e importadora», Boletín Económico, ICE, No. 2885, pp. 9-20.

EUROPEAN COMMISSION (2014). «Drivers of SME Internationalisation: Implications for Firm Growth and Competitiveness», Background Study for the European Competitiveness Report 2014.

GALÁN LUCHA, E. and C. MARTíN MACHUCA (2012). «La estabilidad de las relaciones comerciales de las empresas exportadoras españolas: un análisis microeconómico de sus determinantes», Boletín Económico, April, Banco de España.

GARCÍA C. and E. PRADES (2015). «La estabilidad de las relaciones comerciales de las empresas exportadoras españolas: un análisis microeconómico de sus determinantes», Boletín Económico, April, Banco de España.

GONZÁLEZ SANZ. M.J. and C. MARTíN MACHUCA (2015). «Actualización de la función de las exportaciones españolas de bienes» Economic Bulletin, April, Banco de España.

GUMPERT A., A. MOXNES, N. RAMONDO AND F. TINTELNOT (2017). «The Life-Cycle Dynamics of Exporters and Multinational Firms", CESifo Working Paper, nº 6758.

HELPMAN, E. (2006). "Trade, FDI, and the Organization of Firms», Journal of Economic Literature, vol. XLIV, September, pp. $589-630$

MARTÍN MACHUCA, C., A. RODRÍGUEZ and P. TELLO (2009). «Determinantes principales de la decisión de exportar de las empresas españolas", Boletín Económico, December, Banco de España.

MARTíN, C., and A. RODRÍGUEZ (2009). «Una aproximación a las características de las empresas exportadoras españolas", Boletín Económico, May, Banco de España.

MAURO, F., G. OTTAVIANO and D. TAGLIONI (2007). "Deeper, Wider and More Competitive? Monetary Integration, Eastern Enlargement and Competitiveness in the European Union", ECB Working Paper Series, No 847. 


\title{
BANCO DE ESPAÑA PUBLICATIONS
}

\author{
OCCASIONAL PAPERS
}

1201 ELOÍSA ORTEGA and JUAN PEÑALOSA: The Spanish economic crisis: key factors and growth challenges in the euro area. (There is a Spanish version of this edition with the same number).

1202 MARÍA J. NIETO: What role, if any, can market discipline play in supporting macroprudential policy?

1203 CONCHA ARTOLA and ENRIQUE GALÁN: Tracking the future on the web: construction of leading indicators using internet searches. (There is a Spanish version of this edition with the same number).

1204 JOSÉ LUIS MALO DE MOLINA: Luis Ángel Rojo en el Banco de España.

1205 PABLO HERNÁNDEZ DE COS and CARLOS THOMAS: El impacto de la consolidación fiscal sobre el crecimiento económico. Una ilustración para la economía española a partir de un modelo de equilibrio general.

1206 GALO NUÑO, CRISTINA PULIDO and RUBÉN SEGURA-CAYUELA: Long-run growth and demographic prospects in advanced economies.

1207 IGNACIO HERNANDO, JIMENA LLOPIS and JAVIER VALLÉS: Los retos para la política económica en un entorno de tipos de interés próximos a cero.

1208 JUAN CARLOS BERGANZA: Fiscal rules in Latin America: a survey.

1209 ÁNGEL ESTRADA and EVA VALDEOLIVAS: The fall of the labour income share in advanced economies.

1301 ETTORE DORRUCCI, GABOR PULA and DANIEL SANTABÁRBARA: China's economic growth and rebalancing.

1302 DANIEL GARROTE, JIMENA LLOPIS and JAVIER VALLÉS: Los canales del desapalancamiento del sector privado: una comparación internacional.

1303 PABLO HERNÁNDEZ DE COS and JUAN F. JIMENO: Fiscal policy and external imbalances in a debt crisis: the Spanish case.

1304 ELOÍSA ORTEGA and JUAN PEÑALOSA: Algunas reflexiones sobre la economía española tras cinco años de crisis.

1401 JOSÉ MARÍA SERENA and EVA VALDEOLIVAS: Integración financiera y modelos de financiación de los bancos globales.

1402 ANTONIO MONTESINOS, JAVIER J. PÉREZ and ROBERTO RAMOS: El empleo de las Administraciones Públicas en España: caracterización y evolución durante la crisis.

1403 SAMUEL HURTADO, PABLO MANZANO, EVA ORTEGA and ALBERTO URTASUN: Update and re-estimation of the Quarterly Model of Banco de España (MTBE).

1404 JUAN CARLOS BERGANZA, IGNACIO HERNANDO and JAVIER VALLÉS: Los desafíos para la política monetaria en las economías avanzadas tras la Gran Recesión.

1405 FERNANDO LÓPEZ VICENTE and JOSÉ MARÍA SERENA GARRALDA: Macroeconomic policy in Brazil: inflation targeting, public debt structure and credit policies.

1406 PABLO HERNÁNDEZ DE COS and DAVID LÓPEZ RODRÍGUEZ: Tax structure and revenue-raising capacity in Spain: A comparative analysis with the UE. (There is a Spanish version of this edition with the same number).

1407 OLYMPIA BOVER, ENRIQUE CORONADO and PILAR VELILLA: The Spanish survey of household finances (EFF): description and methods of the 2011 wave.

1501 MAR DELGADO TÉLLEZ, PABLO HERNÁNDEZ DE COS, SAMUEL HURTADO and JAVIER J. PÉREZ: Extraordinary mechanisms for payment of General Government suppliers in Spain. (There is a Spanish version of this edition with the same number).

1502 JOSÉ MANUEL MONTERO y ANA REGIL: La tasa de actividad en España: resistencia cíclica, determinantes y perspectivas futuras.

1503 MARIO IZQUIERDO and JUAN FRANCISCO JIMENO: Employment, wage and price reactions to the crisis in Spain: Firm-level evidence from the WDN survey.

1504 MARÍA DE LOS LLANOS MATEA: La demanda potencial de vivienda principal.

1601 JESÚS SAURINA and FRANCISCO JAVIER MENCÍA: Macroprudential policy: objectives, instruments and indicators. (There is a Spanish version of this edition with the same number)

1602 LUIS MOLINA, ESTHER LÓPEZ y ENRIQUE ALBEROLA: El posicionamiento exterior de la economía española.

1603 PILAR CUADRADO and ENRIQUE MORAL-BENITO: Potential growth of the Spanish economy. (There is a Spanish version of this edition with the same number).

1604 HENRIQUE S. BASSO and JAMES COSTAIN: Macroprudential theory: advances and challenges.

1605 PABLO HERNÁNDEZ DE COS, AITOR LACUESTA and ENRIQUE MORAL-BENITO: An exploration of real-time revisions of output gap estimates across European countries.

1606 PABLO HERNÁNDEZ DE COS, SAMUEL HURTADO, FRANCISCO MARTÍ and JAVIER J. PÉREZ: Public finances and inflation: the case of Spain. 
1607 JAVIER J. PÉREZ, MARIE AOURIRI, MARÍA M. CAMPOS, DMITRIJ CELOV, DOMENICO DEPALO, EVANGELIA PAPAPETROU, JURGA PESLIAKAITE, ROBERTO RAMOS and MARTA RODRÍGUEZ-VIVES: The fiscal and macroeconomic effects of government wages and employment reform.

1608 JUAN CARLOS BERGANZA, PEDRO DEL RíO and FRUCTUOSO BORRALLO: Determinants and implications of low global inflation rates.

1701 PABLO HERNÁNDEZ DE COS, JUAN FRANCISCO JIMENO and ROBERTO RAMOS: The Spanish public pension system: current situation, challenges and reform alternatives. (There is a Spanish version of this edition with the same number).

1702 EDUARDO BANDRÉS, MARÍA DOLORES GADEA-RIVAS and ANA GÓMEZ-LOSCOS: Regional business cycles across Europe.

1703 LUIS J. ÁLVAREZ and ISABEL SÁNCHEZ: A suite of inflation forecasting models,

1704 MARIO IZQUIERDO, JUAN FRANCISCO JIMENO, THEODORA KOSMA, ANA LAMO, STEPHEN MILLARD, TAIRI RÕÕM and ELIANA VIVIANO: Labour market adjustment in Europe during the crisis: microeconomic evidence from the Wage Dynamics Network survey.

1705 ÁNGEL LUIS GÓMEZ and M. ${ }^{a}$ DEL CARMEN SÁNCHEZ: Indicadores para el seguimiento y previsión de la inversión en construcción.

1706 DANILO LEIVA-LEON: Monitoring the Spanish Economy through the Lenses of Structural Bayesian VARs.

1707 OLYMPIA BOVER, JOSÉ MARÍA CASADO, ESTEBAN GARCÍA-MIRALLES, JOSÉ MARÍA LABEAGA and ROBERTO RAMOS: Microsimulation tools for the evaluation of fiscal policy reforms at the Banco de España.

1708 VICENTE SALAS, LUCIO SAN JUAN and JAVIER VALLÉS: The financial and real performance of non-financial corporations in the euro area: 1999-2015.

1709 ANA ARENCIBIA PAREJA, SAMUEL HURTADO, MERCEDES DE LUIS LÓPEZ and EVA ORTEGA: New version of the Quarterly Model of Banco de España (MTBE).

1801 ANA ARENCIBIA PAREJA, ANA GÓMEZ LOSCOS, MERCEDES DE LUIS LÓPEZ and GABRIEL PÉREZ QUIRÓS: A short-term forecasting model for the Spanish economy: GDP and its demand components.

1802 MIGUEL ALMUNIA, DAVID LÓPEZ-RODRÍGUEZ and ENRIQUE MORAL-BENITO: Evaluating the macro-representativeness of a firm-level database: an application for the Spanish economy.

1803 PABLO HERNÁNDEZ DE COS, DAVID LÓPEZ RODRÍGUEZ and JAVIER J. PÉREZ: The challenges of public deleveraging. (There is a Spanish version of this edition with the same number).

1804 OLYMPIA BOVER, LAURA CRESPO, CARLOS GENTO and ISMAEL MORENO: The Spanish Survey of Household Finances (EFF): description and methods of the 2014 wave.

1805 ENRIQUE MORAL-BENITO: The microeconomic origins of the Spanish boom.

1806 BRINDUSA ANGHEL, HENRIQUE BASSO, OLYMPIA BOVER, JOSÉ MARÍA CASADO, LAURA HOSPIDO, MARIO IZQUIERDO, IVAN A. KATARYNIUK, AITOR LACUESTA, JOSÉ MANUEL MONTERO and ELENA VOZMEDIANO: Income, consumption and wealth inequality in Spain. (There is a Spanish version of this edition with the same number).

1807 MAR DELGADO-TÉLLEZ and JAVIER J. PÉREZ: Institutional and economic determinants of regional public debt in Spain.

1808 CHENXU FU and ENRIQUE MORAL-BENITO: The evolution of Spanish total factor productivity since the Global Financial Crisis.

1809 CONCHA ARTOLA, ALEJANDRO FIORITO, MARÍA GIL, JAVIER J. PÉREZ, ALBERTO URTASUN and DIEGO VILA: Monitoring the Spanish economy from a regional perspective: main elements of analysis.

1810 DAVID LÓPEZ-RODRÍGUEZ and CRISTINA GARCÍA CIRIA: Estructura impositiva de España en el contexto de la Unión Europea.

1811 JORGE MARTÍNEZ: Previsión de la carga de intereses de las Administraciones Públicas.

1901 CARLOS CONESA: Bitcoin: a solution for payment systems or a solution in search of a problem? (There is a Spanish version of this edition with the same number).

1902 AITOR LACUESTA, MARIO IZQUIERDO and SERGIO PUENTE: An analysis of the impact of the rise in the national minimum wage in 2017 on the probability of job loss. (There is a Spanish version of this edition with the same number).

1903 EDUARDO GUTIÉRREZ CHACÓN and CÉSAR MARTíN MACHUCA: Exporting Spanish firms. Stylized facts and trends.

\section{BANCODEESPAÑA}

Eurosistema
Unidad de Servicios Auxiliares

Alcalá, 48 - 28014 Madrid

E-mail: publicaciones@bde.es www.bde.es 